\title{
New evidence for a grounded Irish Sea glaciation of the Isles of Scilly, UK
}

\author{
John F. Hiemstra ${ }^{\mathrm{a}, *}$, David J.A. Evans ${ }^{\mathrm{b}}$, James D. Scourse ${ }^{\mathrm{c}}$, Danny McCarroll ${ }^{\mathrm{a}}$, \\ Mark F.A. Furze ${ }^{\mathrm{d}}$, Ed Rhodes ${ }^{\mathrm{e}}$ \\ ${ }^{a}$ Department of Geography, University of Wales Swansea, Singleton Park, Swansea SA2 8PP, Wales, UK \\ ${ }^{\mathrm{b}}$ Department of Geography, University of Durham, Durham DH1 3LE, England, UK \\ ${ }^{\mathrm{c}}$ School of Ocean Sciences, University of Wales, Menai Bridge, Anglesey LL59 5EY, Wales, UK \\ ${ }^{\mathrm{d}}$ Department of Earth and Atmospheric Science, University of Alberta, Edmonton, T6G 2 E3 Canada \\ ${ }^{\mathrm{e}}$ Research School of Earth Sciences, The Australian National University, Canberra ACT 0200, Australia
}

Received 16 October 2003; accepted 19 January 2005

\begin{abstract}
New geomorphological and sedimentological data support previously published reconstructions of an Irish Sea Glacier advance as far south as the northern shores of the Isles of Scilly in the Celtic Sea $\left(49^{\circ} 58^{\prime} \mathrm{N}\right)$. Offshore, boulder-covered bars with cores of diamicton are interpreted as moraines, which together with onshore moraine ridges and trimlines mark the maximal extent of the Irish Sea Glacier. At Bread and Cheese Cove, St. Martin's, a heterogeneous sediment unit, wedged between periglacial gelifluctates, is interpreted as a mixture of glacitectonized and cannibalized glacilacustrine and marine deposits as well as primary subglacial tills. Macrofabric signatures reflect a subglacial origin, but the whole unit has been subject to down-slope mass movement. Micromorphological analysis indicates highly variable response to deformation and glacitectonism, with most features relating to ductile behaviour and wet deformation. The characteristics suggest deposition during a short-lived advance of the Irish Sea Glacier over pre-existing marine and contemporaneous proglacial lacustrine sediments. Once blocks of stratified sediment and diamicton had been driven onshore, they were subject to paraglacial remobilization, resulting at most locations in complete disaggregation. The distribution of re-worked glacigenic sediments coincides with the glacial limits inferred from the geomorphological evidence.
\end{abstract}

(C) 2005 Elsevier Ltd. All rights reserved.

\section{Introduction}

During the Last Glaciation, when global sea levels were eustatically depressed, the largest glacier draining ice from the British and Irish ice domes flowed southwards down the Irish Sea basin. However, the maximum extent of the Irish Sea Glacier, and the conditions during deglaciation, remain poorly understood and strongly contested. Many reconstructions (e.g. Boulton et al., 1991; Lambeck, 1993) place the limit of the ice

\footnotetext{
${ }^{*}$ Corresponding author. Tel.: + 441792295143 ; fax: + 441792207556

E-mail address: j.hiemstra@swansea.ac.uk (J.F. Hiemstra).
}

across the Irish Sea between Pembrokeshire and Wexford, at about $52^{\circ} \mathrm{N}$. However, there is on-shore sedimentary evidence that Irish Sea ice extended around the south coast of Ireland, almost as far as Cork (Evans and Ó Cofaigh, 2003), and on the basis of offshore evidence, Scourse and Furze (2001) have suggested that grounded ice deposited subglacial till as much as $300 \mathrm{~km}$ south of Pembrokeshire (Fig. 1a). Scourse and Furze (2001) argue that glacimarine deposits occur only to the south of this glacial limit, where the basin is deep enough to remain flooded even during times of low eustatic sea level. In contrast, Eyles and McCabe (1989) have argued that glacimarine deposits are widespread all around the Irish Sea basin, extending to well above the 

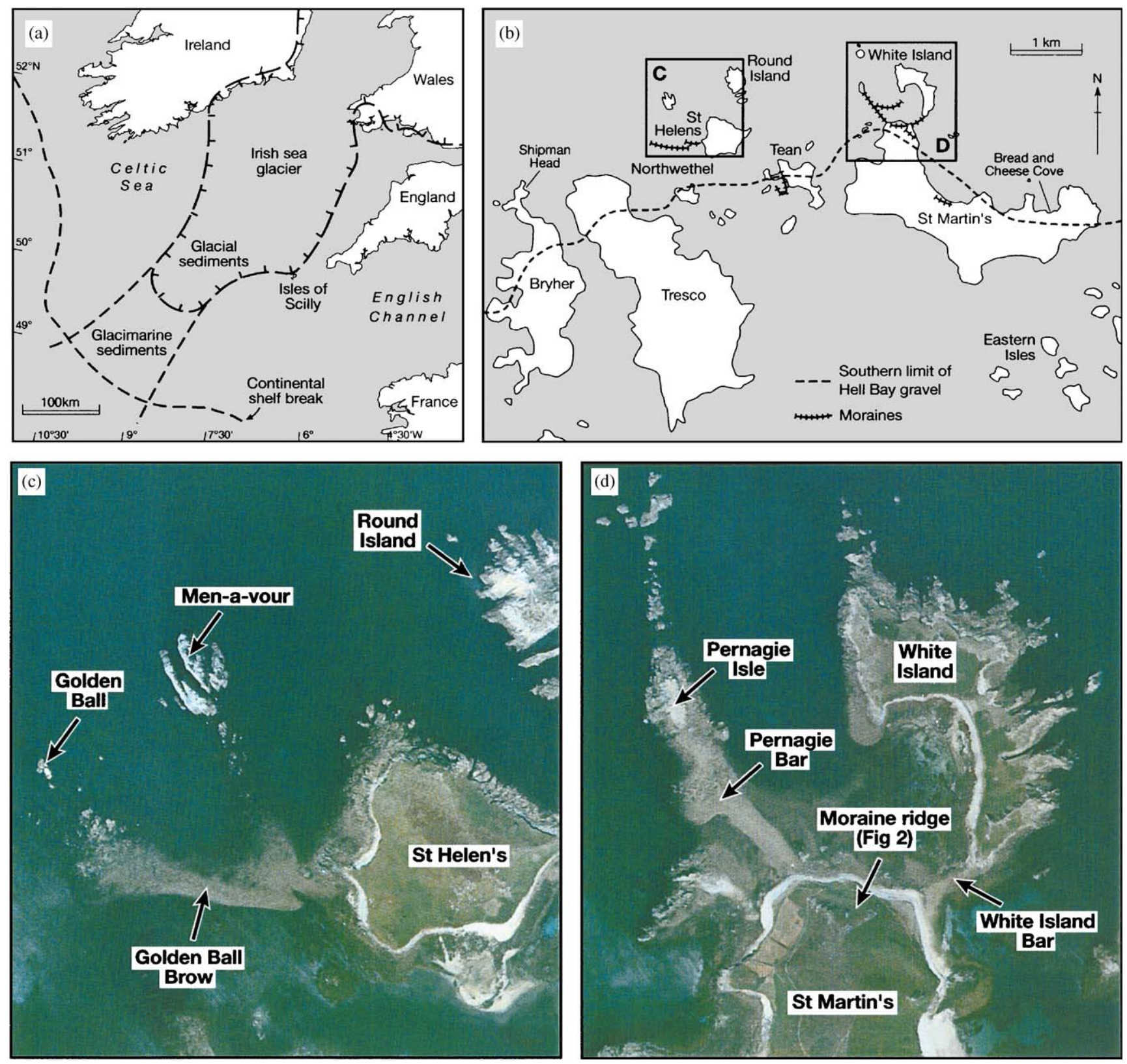

Fig. 1. (a) Location map of the Isles of Scilly showing limits of the offshore LGM glacial sediments and glacimarine sediments (after Scourse et al., 1990). (b) Map showing northern Isles of Scilly, with locations referred to in the text. Note the limit of the Hell Bay Member and the distribution of the landforms that comprise the proposed system of moraines and trimlines. (c) Aerial photograph of Golden Ball Brow, a dual intertidal ridge off the west coast of St. Helen's. The ridge is interpreted as a moraine. (d) Aerial photograph showing St. Martin's and White Island with Pernagie and White Island Bars and connecting onshore moraine. (Figs. 1c and 1d are reproduced with kind permission of Global Mapping Limited and XYZ Digital Map Company/English Nature).

present sea level, with local relative sea levels controlled by isostatic depression. The debate between proponents of the 'glacimarine' and 'terrestrial' models continues (see McCarroll, 2001 for a critique).

Both the extent of the Irish Sea Glacier and the conditions during deglaciation can be tested on the Isles of Scilly $\left(49^{\circ} 58^{\prime} \mathrm{N} 06^{\circ} 21^{\prime} \mathrm{W}\right.$; $45 \mathrm{~km}$ WSW of Land's End: Figs. 1a and b). The presence of erratic-bearing glacigenic sediments on the northern shores of these granite islands has been known for almost a century (Barrow, 1906), but their origin remains uncertain. If the landscape or sediments retain evidence of grounded ice, as suggested by Mitchell and Orme (1967), Scourse (1991a,b) and Scourse and Furze (2001), then the Irish Sea Glacier must, at some time, have extended well beyond the coast of Wales. If, however, they are distal 
glacimarine deposits, as proposed by Eyles and McCabe (1989), then the ice limit must have been to the north and relative sea levels higher than today, requiring isostatic depression far south of the ice limit and providing strong support to the glacimarine model.

\section{Methods}

Aerial photographs were used to map possible glacial depositional features both onshore and in the shallow offshore areas of the northern islands. Additionally, sedimentological and structural logging, clast macrofabrics and structural measurements were combined with microscopic analyses to facilitate interpretations of former depositional environments. Scourse (1991a) initially measured macrofabrics on clast $A$-axes at different levels in four sediment units $\left(n=50 ; \mathrm{F}_{\mathrm{s} 1}, \mathrm{~F}_{\mathrm{s} 3}\right.$, $\mathrm{F}_{\mathrm{s} 5}, \mathrm{~F}_{\mathrm{PB}}, \mathrm{F}_{\mathrm{BCB}}$ and $\left.\mathrm{F}_{\mathrm{WIB}}\right)$. To account for newly discovered details, two further macrofabrics $(n=50$; $\mathrm{F}_{\mathrm{s} 2}$ and $\mathrm{F}_{\mathrm{s} 4}$ ), based upon clast $A-B$ planes, were sampled from the central parts of one of the units. The $A-B$ planes are thought to rotate towards parallelism with the principal axis of extensional strain in a deforming medium or the plane of slip during brittle deformation (Benn and Evans, 1996). Macrofabrics were plotted as Schmidt equal area projections using the Rockware ${ }^{\mathrm{TM}}$ stereo programme and contoured using the Gaussian weighting factor. The fabric shape triangle of Benn (1994) was employed in the comparison of macrofabric strengths with previous studies. Finally, a total of 11 micromorphological samples, representing three stratigraphic units and their contacts, were prepared following impregnation and thin sectioning procedures described by van der Meer (1996). The thin sections, which range in size from 40 to $50 \mathrm{~cm}^{2}$, were examined using a standard low magnification (between 4-32 $\times$ ) petrographic microscope.

\section{Late Quaternary stratigraphy of the Isles of Scilly}

The stratigraphy of the Isles of Scilly comprises sediments grouped into the St. Mary's and St. Martin's Formations (Campbell et al., 1999). The St. Mary's Formation consists of the Watermill Member, a basal raised beach gravel of probable interglacial age, overlain by the Porthloo Member, a poorly sorted, organicbearing breccia, consisting of angular local granite clasts in a matrix of granules, sand and silt. The St. Martin's Formation contains five members all of which are related to the glaciation of the northern Isles of Scilly: the Bread and Cheese, Hell Bay, Old Man, Tregarthen and Scilly Members.

The stratotype of the Scilly Member (Campbell et al., 1999; or the Scilly Till Member sensu Scourse, 1986, 1991a) is at Bread and Cheese Cove on St. Martin's (Fig. 1b), where a sharp contact separates it from the underlying Porthloo Member. The Scilly Member is a pale-brown diamicton containing siliceous microfossils as well as a wide range of clast lithologies, including erratics. Overlying the Scilly Member is the Tregarthen Member, a well-sorted sandy gravel with a broad range of lithologies, and the Hell Bay Member, a deposit of pebbles of varied lithology in a matrix of sandy silt. The Hell Bay Member, which has been genetically linked to the Scilly Member and the Tregarthen Members based on erratic content and composition (Scourse, 1991a), is not present at Bread and Cheese Cove but is widespread at many sites in the northern Isles of Scilly (Scourse, 1991a; Scourse and Furze, 2001). The stratigraphically youngest Bread and Cheese Member comprises angular granite clasts and occasional erratics in a matrix of granules, sand and silt. The Old Man Member consists of aeolian sandy loess and is distributed widely outside the glacial limit in the southern Scillies (Scourse, 1991a; Scourse and Furze, 2001).

\section{Previous evidence of glaciation on the Isles of Scilly}

Some of the sediments described above have previously been proposed as evidence of the presence of grounded glacier ice on the northern coasts of the Isles of Scilly (e.g. Scourse, 1991a; Scourse and Furze, 2001). Striated and faceted erratics, derived from outcrops located north of the Scillies in the Celtic Sea, as well as fragmented siliceous sponge spicules, are common or abundant in the Scilly Member. The position of the grounded ice margin has been reconstructed based on the presence of the Scilly Member diamicton (Scourse, 1991a) and the southern limit of the Hell Bay Member has been used as a proxy for the maximum glaciation limit (Mitchell and Orme, 1967; Scourse, 1991a; Scourse and Furze, 2001; see Fig. 1b).

Supporting evidence for this reconstruction is the distribution of smooth, possibly glacially eroded granite tors inside, and more elaborate, castellated tors south of the proposed limit (see Scourse, 1991a; Scourse and Furze, 2001). The difference is reminiscent of mountaintop trimlines mapped elsewhere (Ballantyne et al., 1998). The occurrence of coarse aeolian silt (Old Man Member), which is seemingly restricted to the southern Scillies and genetically linked to the Scilly Member (Catt, 1986; Scourse and Furze, 2001), also supports the reconstructed glaciation limit running across the northern islands.

The age of the glaciation that reached the Isles of Scilly remains uncertain and recent attempts to apply a combination of OSL and cosmogenic isotope exposureage dating techniques has produced equivocal results (Scourse et al., 2004). The balance of available dating 
evidence, however (radiocarbon and TL; Scourse, 1991a), suggests that it is Late Quaternary and probably Oxygen Isotope Stage 2 (Late Devensian).

\section{New evidence for glaciation on the Isles of Scilly}

\subsection{Moraines}

Scourse and Furze (2001) previously suggested a spatial relationship between the glacigenic sediments and marine landforms in the northern Scillies. They found that a large number of marine bars are located within the limit of the Hell Bay Member and that the composition of these bars is indicative of a primary glacial origin. Scourse (1991a) had already found that Pernagie Bar and White Island Bar on St. Martin's have a core of diamictic sediments that resemble the Scilly Member and that many of the exposed boulders in the ridges are erratics from northerly sources. Assessment of the morphology of coastal features visible on aerial photographs suggests that Pernagie Bar and White Island Bar are ice-marginal moraines (Figs. 1b and d). Additionally, numerous other features in the northern Scillies (see below) are best explained as ice-marginal ridges that form a system of moraines and trimlines marking the maximal extent of the Irish Sea Glacier (Fig. 1b).

Based on form-analogy with St. Patrick's Bridge at Kilmore Quay, Co. Wexford (Ó Cofaigh and Evans, 2001b), we propose that the diamicton-cored and boulder-covered intertidal ridge called Golden Ball Brow on the west coast of St. Helen's (Fig. 1c) is also a moraine. This feature comprises two parallel ridges, likely to represent ice-margin positions (Figs. 1b and c). Similarly, the curvilinear offshoot from Pernagie Bar towards the east forms a dual ridge feature with the subparallel White Island Bar (Figs. $1 \mathrm{~b}$ and d).

On land, the best evidence of glacial landform construction is on St. Martin's. At the northern end of the island, there are clear, smoothly crested, symmetrical ridges, typically $2-3 \mathrm{~m}$ high and up to tens of metres long, which connect Pernagie Bar and White Island Bar to form a lobate feature (Figs. 1b, d and 2). Towards the southeast on St. Martin's, on the gentle slopes facing Great Bay, marked breaks in slope or asymmetric ledges associated with small kettle-like depressions are likely remnants of ice-contact slopes (Fig. 1b). The positions roughly coincide with the local southern limit of the Hell Bay Member.

Ridge-like expressions were also identified on St. Martin's towards Bread and Cheese Cove, and there are several ridges and concentrations of boulders on Bryher, Tresco and St. Helen's. One of the clearest lies on the eastern side of Shipman Head, at the northern end of Bryher. The positions of these phenomena are consistent

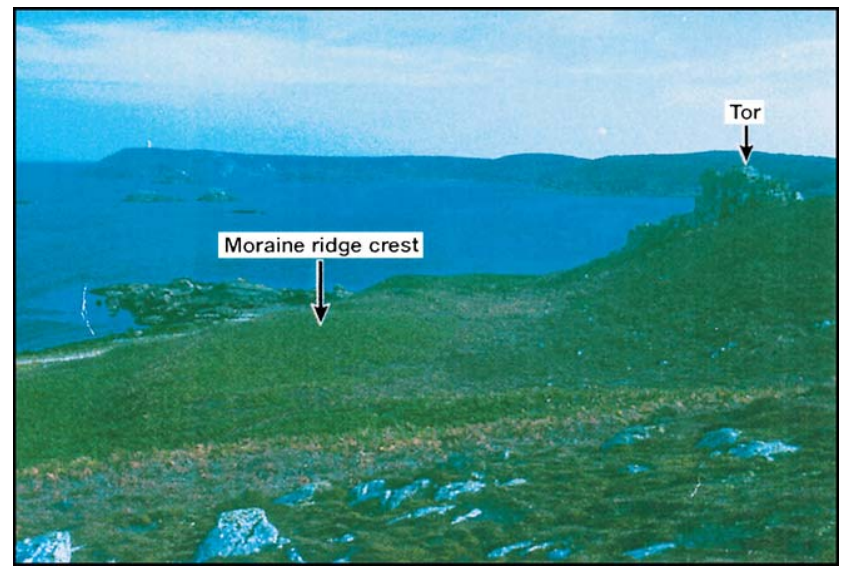

Fig. 2. Ground photograph of the moraine that forms the onshore extension of Pernagie Bar on the northern tip of St. Martin's. The tor lies just beyond the glacier margin. See also Fig. 1d.

with glacier advance on to the northern islands and the penetration of ice lobes into the adjacent sounds, but without evidence of erratics or till cores this interpretation must remain tentative.

\subsection{The Scilly Member at Bread and Cheese Cove, St. Martin's}

Bread and Cheese Cove is currently the only exposure of the Scilly Member. The sediments are confined in an up to $1.55 \mathrm{~m}$ thick lens that is wedged between the Porthloo Member and the Bread and Cheese Member (Fig. 3). The wavy and relatively sharp contacts with these gelifluction deposits (cf. Scourse, 1991a) are inclined and dip towards the southeast (Fig. 3c). The basal part of the Scilly Member is a matrix-supported layer of granite boulders (Figs. 3a and b), interpreted by Scourse (1991a) as a lag deposit. Higher in the section, matrix-supported subunits of clayey diamicton, silty diamicton and sandy diamicton, as well as plugs of pure clay, pure sand and locally more clast-supported subunits dominate. Many of these subunits have tapered ends and sharp contacts. Scourse and Furze (2001) considered the boulder lag and the erratics as critical to the interpretation of the Scilly Member as the deposit of a grounded, warm-based Irish Sea Glacier. They argued that the granite lag indicated erosion and entrainment of local material, while the lithologies of farther-travelled materials indicated that the glacier was grounded to the north of the Scillies, at approximately $90-100 \mathrm{~m}$ below present-day sea-level.

Reassessment of the exposure prompts an interpretation of the Scilly Member as a mixture of sediments of different origins that have been eroded from their sources and glacitectonized (Figs. 3a and b). It contains reworked glacilacustrine and marine deposits as well as primary subglacial tills, which have been shunted ashore 

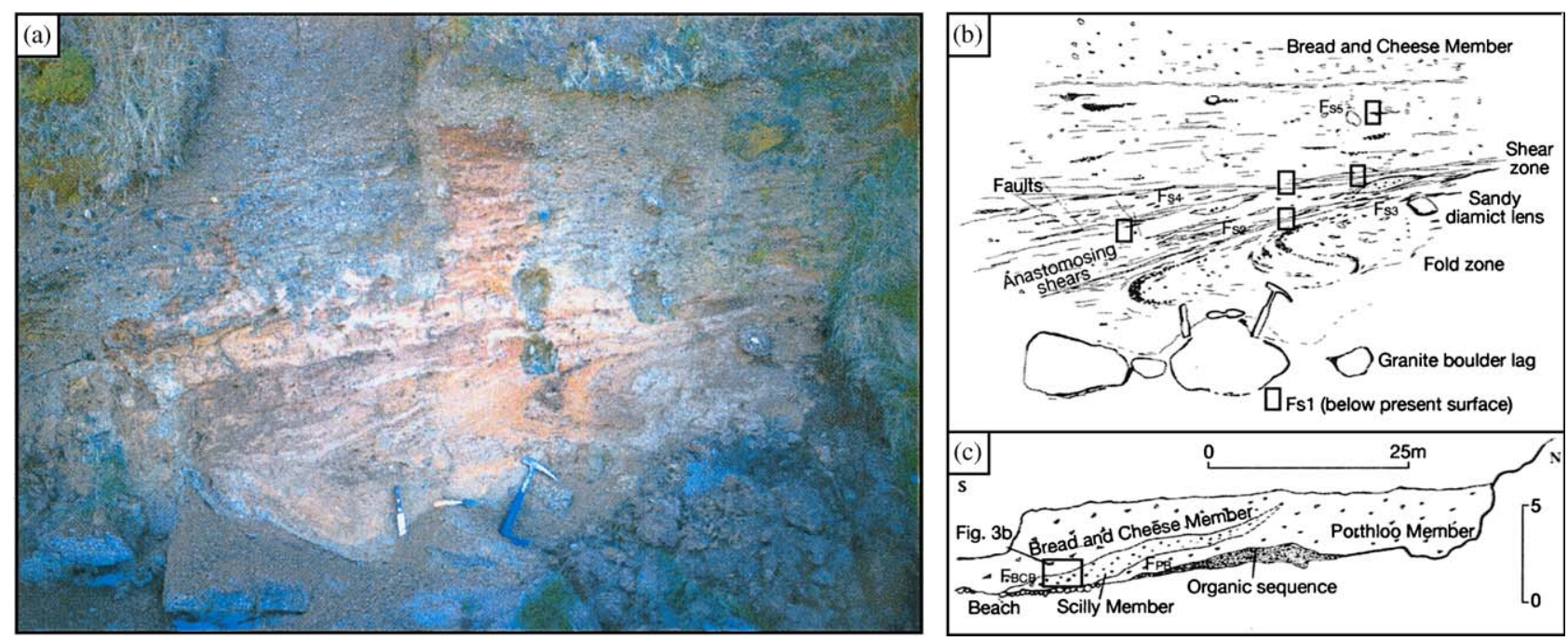

Fig. 3. (a) Photograph of the Scilly Member exposure at Bread and Cheese Cove, St. Martins. (b) Sketch highlighting the shear, fold and fault structures. Note position of the clast fabrics $\left(\mathrm{F}_{\mathrm{Sn}}\right)$ and thin section samples. (c) Generalized section sketch of the cliff at Bread and Cheese Cove, showing architecture, configuration and stratigraphic position of Scilly Member.

as a relatively coherent slab of material. The apparent heterogeneity of the Scilly Member is thus controlled to a large extent by subglacially generated structures.

The dominant structure in the Scilly Member is an inclined shear zone, which is up to $0.5 \mathrm{~m}$ thick near the base at the eastern end and thins to around $0.3 \mathrm{~m}$ towards the upper, western end of the section (Fig. 3a and b). The shear zone is laminated, with many attenuated clayey pods, stringers and lenses throughout the overall clayey to silty laminated diamicton (Dml). The shear zone is slightly sandier and contains more gravel towards its base, while in the upper parts, sandy and gravelly diamictic lenses occur. Normal faults run across the upper boundary and subtle, small-scale anastomosing shear-features occur in an area towards the base of the larger-scale shear zone. Above the shear zone, the Scilly Member appears subhorizontally stratified with a gradual vertical increase in the number of pods and lenses, containing both erratic and granitic pebbles. Below the shear zone, the sediments are heavily folded. Two obvious, apparently overturned and nearly isoclinal features occur (Figs. 3a and b). The upper limbs of the folds are subparallel to the shear zone and contain many disrupted clayey intraclasts and lenses, which suggests a genetic relation. The folds seem to hinge on gravelly, curvilinear pods. One of the folds seems to be composite, with an S-shape developing against an extensive, distinctly clayey plug towards the base of the exposure.

\subsection{Orientations and fabrics}

Scourse (1991a) measured the $A$-axis orientations of clasts in the upper parts of the Scilly Member at White
Island Bar. He found a preferred northwesterly to northerly dipping fabric $\left(\mathrm{F}_{\mathrm{WIB}}\right)$, suggestive of emplacement by onshore flow of the Irish Sea Glacier (Fig. 4). However, fabric data from the Scilly Member at Bread and Cheese Cove, collected on $A$-axes by Scourse (1991a; Figs. 3b and $4-\mathrm{F}_{\mathrm{S} 1}, \mathrm{~F}_{\mathrm{S} 3}$ and $\mathrm{F}_{\mathrm{S} 5}$ ) and on $A / B$ planes in this study (Figs. $3 \mathrm{~b}$ and $4-\mathrm{F}_{\mathrm{S} 2}$ and $\mathrm{F}_{\mathrm{S} 4}$ ), indicate preferential southeasterly to southerly dip directions. Similar to the orientations of planar structures, the fabrics are aligned in directions that are oblique to those at White Island Bar.

Clast fabrics measured from within and above the identified shear zone invariably show SE-dipping clusters with $S_{1}$ eigenvalues ranging from 0.6 to 0.8 . Towards the base of the Scilly Member, the signal is less clear (girdle, $S_{1} \approx 0.5$ ), but the mean dip is still towards south to southeast. The fabrics measured in the transitional zone across the lower contact of the shear zone and the upper limb of the overturned folds show a distribution consisting of two coalesced clusters with high dip angles ( $\mathrm{F}_{\mathrm{S} 2}$ : Figs. $3 \mathrm{~b}$ and 4$)$. Although this specific fabric possibly reflects superimposed shearing and folding events, the outer contours connecting the two clusters depict a NW-SE alignment, matching orientations measured elsewhere in the Scilly Member.

When plotted on a fabric shape triangle (Fig. 5), all samples with the exception of $\mathrm{F}_{\mathrm{S} 1}$, taken from the base of the Scilly Member, display relatively strong clustering. Although many samples also coincide with the deformation till and glacitectonite envelopes reported from previous work on subglacial sediments (Benn and Evans, 1996), clast fabric clustering in the geographical setting of the north Scillies could also be a function of slope processes. An envelope that encompasses 

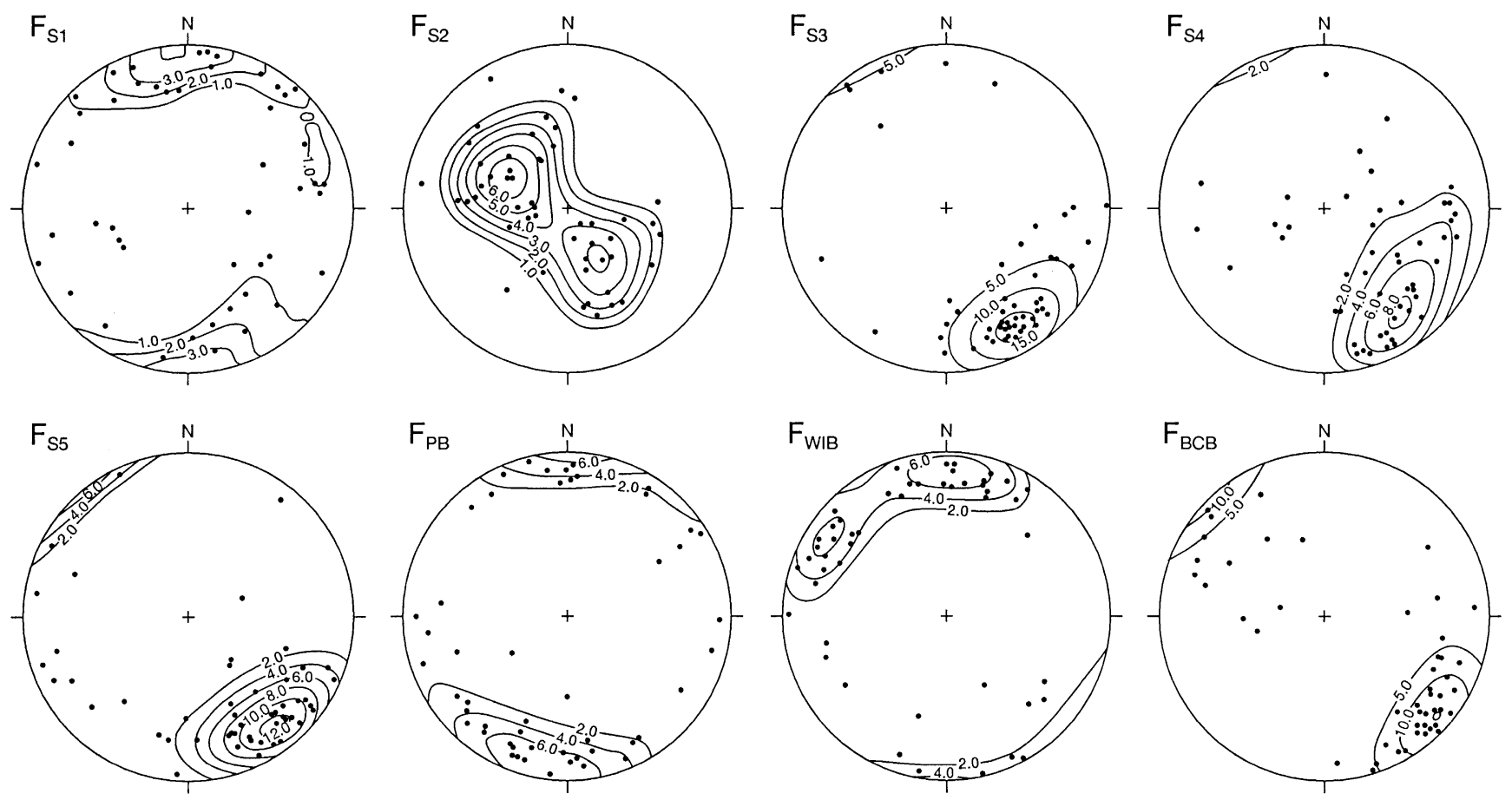

Fig. 4. Clast macrofabrics from the Scilly Isles displayed as Schmidt equal-area projections using Rockware ${ }^{\mathrm{TM}}$ and contoured by the Gaussian weighting factor. For further details see text.

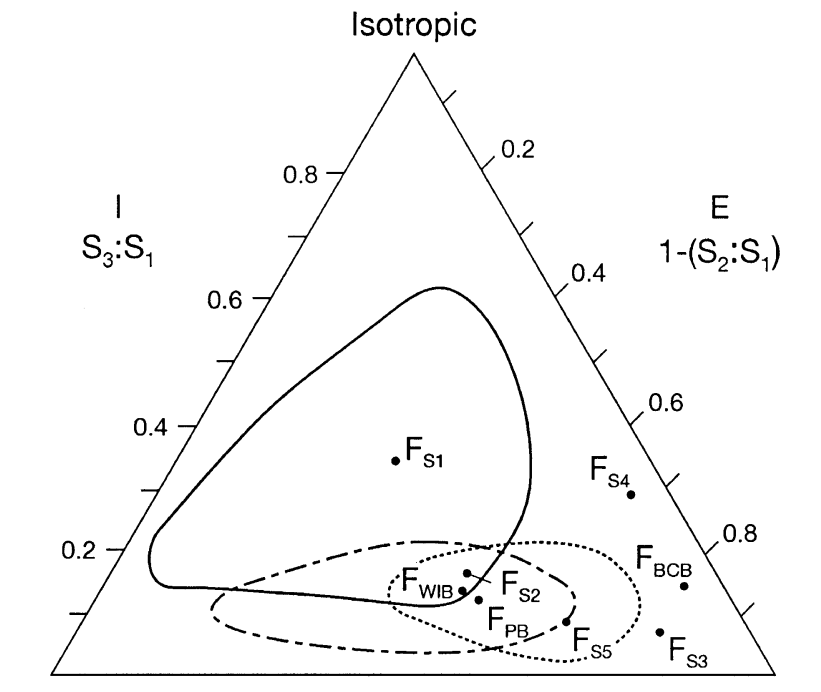

Girdle

Cluster

Fig. 5. Clast fabric shape triangle (after Benn, 1994) with samples taken during this study and by Scourse (1991a). Also shown are envelopes for deformation tills and glacitectonites (solid line and dotted line, respectively; Benn and Evans, 1996) and gelifluction deposits (dashed line; Benn, 1994). Note that the envelopes are based upon $A$-axis data rather than $A / B$ plane data. Given that both $A$-axes and $A / B$ planes were used in this study, sample fabric shapes are not strictly compatible.

previously reported macrofabric data on gelifluction deposits is also included in Fig. 5 (Benn, 1994) for comparison and demonstrates that all the samples falling in the glacitectonite envelope are also covered by gelifluction signatures. Clearly, a subglacial origin can be inferred only by combining macrofabric signatures with other macro-scale structural and microscopic observations. Moreover, superimposed signals are often difficult to differentiate using clast fabric strength in isolation.

Given the inferred genetic relationship between the clayey diamicton core of White Island Bar and the Scilly Member at Bread and Cheese Cove (see Fig. 25 in Scourse, 1991a), the opposing clast fabric signals require explanation as glacier ice flow on to the northern shores of the Isles of Scilly should have imparted a northeasterly dipping clast fabric. However, although the prominent dip directions in the Scilly Member at Bread and Cheese Cove are opposite to those from the same sediment at White Island Bar, all samples display a consistent alignment from NW to SE with a minor NNW-SSE component. Some explanation may be provided by comparison with clast fabrics measured on the Porthloo Member (Fig. 4-F $\mathrm{F}_{\mathrm{PB}}$ ) and Bread and Cheese Member (Fig. 4- $\mathrm{F}_{\mathrm{BCB}}$ ) that lie stratigraphically below and above the Scilly Member, respectively. These sediments, interpreted as periglacial slope deposits, display south to southeasterly clast fabric orientations (Scourse, 1991a), similar to the Scilly Member at Bread and Cheese Cove. The local slope at the site steepens rapidly towards the southeast, suggesting that clasts have adopted slope-parallel alignments and dip back upslope, characteristics very common in gelifluction deposits (e.g. Benedict, 1970; French, 1971; Harris, 
1981). It therefore may be merely coincidence that the former glacier flow direction, as determined by the White Island Bar clast fabric on the Scilly Member, was on the same alignment. However, the redeposition of the Scilly Member after disaggregation is unlikely, because the unit contains isoclinal folds and prominent shear zones indicative of glacitectonic displacement by onshore flowing ice. Modern examples from Svalbard of geliflucted blocks of pre-existing sediment that have not undergone disaggregation are presented in van VlietLanoë (1993). This suggests that the primary fabric signature in the Scilly Member may still reflect a subglacial origin but the whole sediment unit has been subject to a down-slope mass movement after initial emplacement and therefore is not in situ at Bread and Cheese Cove.

\subsection{Micromorphology}

Inferences regarding the origins of some of the main stratigraphic units of the Isles of Scilly can be substantiated by thin section analyses. The Porthloo Member at Bread and Cheese Cove comprises (sub) angular clasts in a plectic, clayey to silty matrix. Long axes orientations are (sub) parallel (locally tiled) to the inclined, sharp contact with the overlying Scilly Member, suggesting that it could represent a glide plane/ narrow shear plane over which the Scilly Member travelled downslope. Microscopic observations are in agreement with the inferred origin as a head deposit (cf. Scourse, 1991a).

The periglacial origin of the Hell Bay Member (Scourse, 1991a) is verified using thin sections from Chad Girt (White Island) and St. Martin's. There are silt cappings, silt-enriched layers or silt droplets (see van der Meer et al., 1992) and open structures with mammilated pore spaces (Figs. 6a and b), which can be related to the translocation of fines, cryogenic sorting and the presence of segregation ice or ice lenses. Locally, the Hell Bay Member shows rounded intraclasts and circular grain arrangements, which may be associated with active layer or slope reworking processes.

The subglacial origin of the Scilly Member is convincingly demonstrated in thin sections from Bread and Cheese Cove. Eight samples cover the sharp, lower contact with the Porthloo Member, the shear zone boundaries and the fold structures (see Fig. 3b for sample locations). Microscopically, the Scilly Member is texturally heterogeneous and laminated, with distinctly clayey zones next to, and interfingering with areas that are diamictic. Millimetre-scale, discontinuous, tectonicstyle laminae are common, particularly in the shear zone. Subhorizontal stringers and streaks, lenses, boudins and attenuated intraclasts, perturbations, pods, wisps and disrupted or brecciated clayey laminae occur (Figs. 6c and d). Within the fold limbs, the Scilly
Member looks more chaotic. It shows both stratified patterns and patchy configurations of diamicton, sand, silt and clay. Clayey intraclasts and inclusions are mainly equidimensional and subangular.

Plasmic fabrics, defined as preferred alignments of clay platelets and showing up as birefringence patterns in cross-polarized light (Brewer, 1976), are most prominent and best developed in the clayey parts of the shear zone in the Scilly Member (Figs. 6e and f). Unidirectional and planar plasmic fabric signals, which are commonly associated with simple shearing (e.g. van der Meer, 1993; van der Wateren, 1999; Menzies, 2000; Hiemstra and Rijsdijk, 2003), occur in, and are mostly (sub) parallel to the long axes of stringers, lenses and attenuated streaks, flames and boudins. The unidirectional plasmic fabrics consist of striated patterns of birefringence, intergrading between thin, long linings (unistrial plasmic fabrics: Brewer, 1976) and broader bands of semi-uniformly oriented plasma (masepic plasmic fabrics: Brewer, 1976). In the clayey, central part of the shear zone and in a clayey bed towards the top of the shear zone, unistrial plasmic fabrics take on the form of bundles of parallel and interweaving lines.

The broad range of identified (microscopic) structures and the spatial variability suggests that the response of the sediments of the Scilly Member to imposed deformation and glacitectonism was highly variable. Most of the features described above point to ductile behaviour and wet deformation. Evidence of the presence of water is widespread and takes the form of inclined to vertical, millimetre-scale water expulsion tracks or escape structures (Fig. 6g). Such structures are particularly common near the shear zone boundaries, which suggests that during shearing, water was expelled from zones in which strain was concentrated. The sizes and shapes of the structures suggest that water expulsion occurred at low energy. Movement of water through the sediment is also reflected in the occurrence of fault-like expressions and small-scale fluidization or flow deformation features. This indicates that some parts of the sediment became drier while other parts became waterlogged in the process of deformation. The parts that became drier, or were already dry prior to deformation, locally exhibit evidence of a brittle response. Particularly near the top of the Scilly Member, a network of fractures was observed, which seems to delineate a structure of blocky, often smooth-edged, rounded aggregates. This aggregation is probably a primary structure, a view supported by the observation of in situ fractured grains close to the edges of the aggregates (Fig. 6h). A cyclic, essentially dry, but porewater-controlled subglacial shearing process, similar to that described by Hiemstra and van der Meer (1997) would account for the associated aggregation and grain fracturing. 

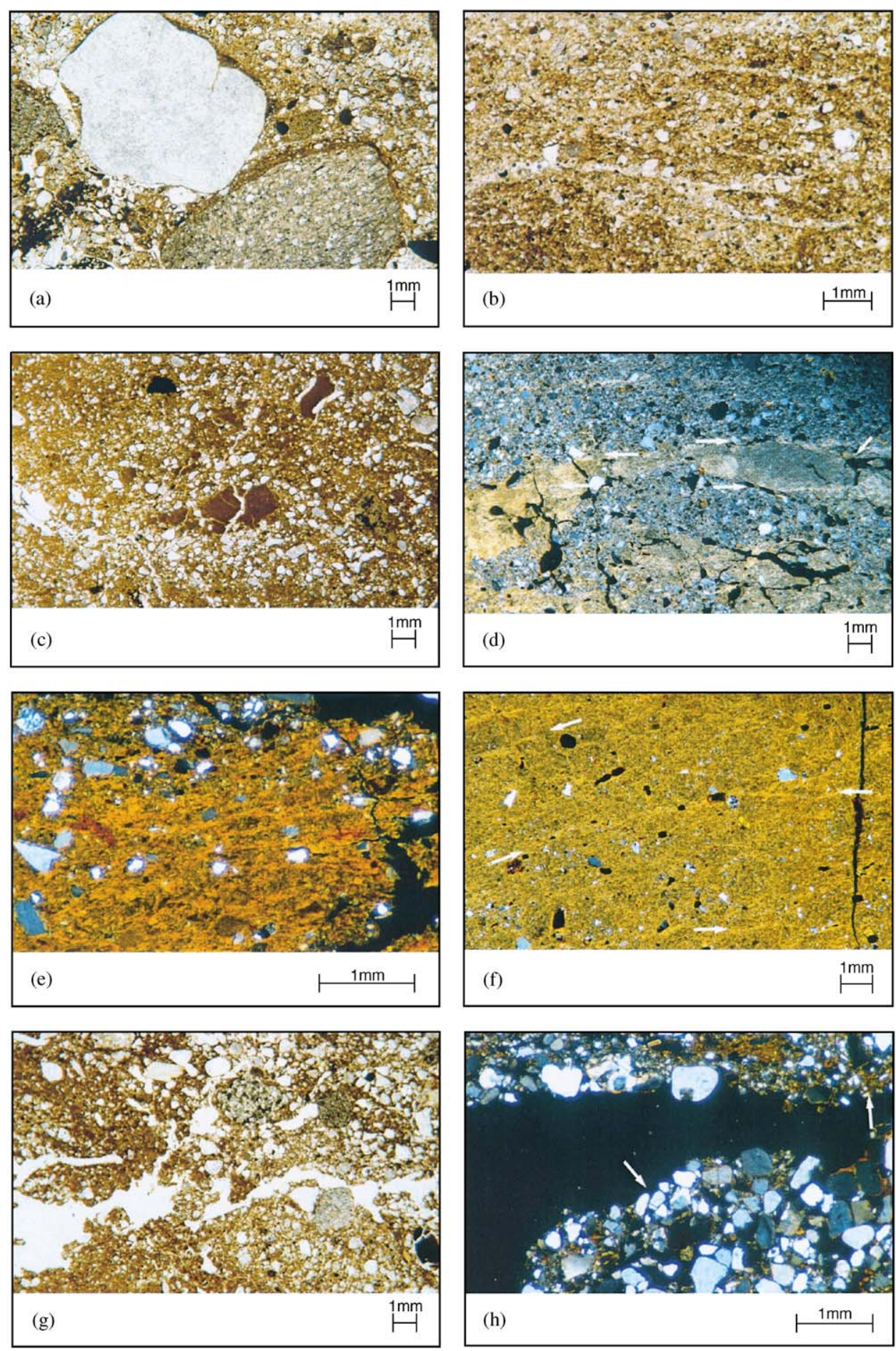

Fig. 6. Selection of photomicrographs. (a) Silt concentrations or cappings on individual grains and clasts. Hell Bay Member, Pernagie Bar. (b) Lenticular silt droplet structure and associated horizontal, linear pore spaces. Hell Bay Member, Chad Girt. (c) Streamlined and brecciated clay boudin. Note arrangement and preferred alignments of silt- and sand-grains conform to boudin shape. Central part Scilly Member shear zone, Bread and Cheese Cove. (d) Tectonic, interfingering lamination. Note bright, unidirectional plasmic fabric patterns locally outlining margins of clayey strata (see arrows). Lower parts Scilly Member, Bread and Cheese Cove. (e) Unidirectional, striated plasmic fabrics representing micro-shears: intergrading unistrial and masepic patterns. Upper part of shear zone, Scilly Member, Bread and Cheese Cove. (f) Thin, continuous unistrial plasmic fabrics indicative of simple shearing (see arrows). Upper part of shear zone, Scilly Member, Bread and Cheese Cove. (g) Irregularly shaped, low oblique fracture with associated translocation of fines indicating low-energy water escape. Just below shear zone boundary Scilly Member, Bread and Cheese Cove. (h) Fractured grains (arrows) at the margin of till aggregate. Upper parts Scilly Member, Bread and Cheese Cove. Note: 10a-c and 10g: plain polarized light. $10 \mathrm{~d}-\mathrm{f}$ and 10h: cross-polarized light. 


\section{Discussion}

The maximum extent of the Irish Sea Glacier has been mapped in the Celtic Sea and on the northern Isles of Scilly using the distribution of the Scilly Member and glacigenic material in the offshore Melville Formation (Scourse, 1986, 1987, 1991a, b; Scourse and Furze, 2001; Scourse et al., 1990, 1991, 2000). The patchy nature of the till located offshore in the Celtic Sea led Wingfield (1994) to suggest that the advance of Irish Sea ice was short-lived. This is echoed in the proposal of Scourse et al. (1990) that the Irish Sea Glacier surged to its maximum position on the northern Scillies. In an assessment of the landforms and sediments that record onshore flow of the Irish Sea Glacier in SE Ireland, Evans and Ó Cofaigh (2003) confirm that the ice margin was dynamic and could have surged to its maximum limit, although the full range of landform-sediment associations normally associated with a surging glacier landsystem (Evans and Rea, 1999, 2003) is not evident in the Irish Sea basin. However, the macroscopic and microscopic structural characteristics of the Scilly Member as described in this paper could all be related to either subglacial or glacitectonic processes and therefore strongly suggest that it was deposited during a short-lived advance of the Irish Sea Glacier over preexisting marine and contemporaneous proglacial lacustrine sediments in a similar fashion to that envisaged for the Irish Sea Tills in South and South-East Ireland (Ó Cofaigh and Evans, 2001a,b; Evans and Ó Cofaigh, 2003).

The Scilly Member comprises a spatially restricted block of glacitectonized stratified sediment, driven onshore by glacier ice flowing over fine-grained, laminated sediments. Large quantities of the Irish Sea Tills were produced in this way, whereby advancing glacier ice thrust, folded and stacked proglacial sediments that had been accumulating in outwash fans and ponded depressions (Thomas and Summers, 1984; O Cofaigh and Evans, 2001a,b; Evans and Ó Cofaigh, 2003). Clast macrofabrics in such sediments contain a range of fabric strengths but often display preferred alignments that document palaeo-ice flow directions, especially where shearing has resulted in the formation of a penetrative glacitectonite (sensu Benn and Evans, 1996). The preservation of pre-existing internal structures in glacially cannibalized blocks of sediment or rafts within the Scilly Member suggests that transport distances were short and emplacement was probably ice marginal.

Micromorphological evidence of water escape structures in the Scilly Member reveals that the parent sediment locally contained abundant porewater that was squeezed out along strain boundaries during shearing. Water escape is manifest at a range of scales in the Irish Sea Tills and has been interpreted elsewhere as evidence of elevated porewater pressures due to rapid glacier advance against local slopes (Rijsdijk et al., 1999; Evans and Ó Cofaigh, 2003). We envisage a similar depositional setting on the north shores of the Isles of Scilly.

The steep slopes along the northern shores are likely locations for paraglacial reworking, particularly under periglacial conditions (McCarroll and Rijsdijk, 2003). Once blocks of stratified sediment and diamicton had been driven onshore by the Irish Sea Glacier ice they were subject to mass wasting processes. This was responsible for complete disaggregation of glacigenic material in locations where a short-lived glacier advance deposited only thin subglacial deposits, thereby explaining the widespread deposition of the Hell Bay Member, a diamicton interpreted as periglacially reworked till, and the paucity of depositional evidence for glacier incursion onto the Scillies. Problems in defining former glacial limits in such settings often arise where glaciers deposited only thin tills and patchy moraine forms, for example the Wolverhampton Line in the English Midlands (e.g. Wills, 1924, 1938) and the Irish Sea Drift limit in SE Ireland. This has been addressed by Evans and Ó Cofaigh (2003) in their incorporation of Boulton's (1996a,b) model of till deposition patterns in the reconstruction of Irish Sea Glacier incursion into SE Ireland and the Celtic Sea. Specifically, till thickness declines sharply beyond a submarginal zone of maximum deposition, especially where glacier advance was short-lived.

The argument that the glacigenic deposits of the Isles of Scilly are distal glacimarine deposits forming part of an extensive 'mud drape' around the basin (Eyles and McCabe, 1989) can be categorically rejected. The section at Bread and Cheese Cove contains blocks of subaqueously deposited sediments, both marine and glacilacustrine, but the deformation structures, at both macro- and micro-scales, indicate that these have been glacitectonized and carried on-land by a grounded Irish Sea Glacier. The glacial landforms and sediments of the Isles of Scilly record deposition by an Irish Sea Glacier during a time of low, eustatically depressed sea levels. There is no evidence in support of the glacimarine model for deglaciation of the Irish Sea.

The interpretation that the Scilly Member at Bread and Cheese Cove is not in situ and has been remobilized downslope after deposition has implications for the interpretation of the age of the glaciation concerned. This is important because the conclusion that the Scilly Member is Late Devensian in age (Scourse, 1991a) has not been widely accepted (cf. Scourse and Furze, 2001). Indeed, Bowen (1984) has previously suggested that, because the Irish Sea tills are soliflucted, they must be older than the underlying basal raised beach units. There is no logic in this reversal of the stratigraphic principle, and the fact that the glacial sediments have moved downslope provides no evidence for their age. Paraglacial remobilization of glacial deposits on even 
gentle slopes is the norm rather than the exception, and it occurs all around the Irish Sea basin (McCarroll and Rijsdijk, 2003). Evidence in support of the Late Devensian interpretation remains the large number of sections where the Porthloo Member, with its contained dated organic material (Scourse, 1991a), lies stratigraphically beneath the Scilly, Tregarthen and Hell Bay members, and the genetic relationship between the Scilly Member and the TL (Wintle, 1981) and OSL (Smith et al., 1990) dated Old Man Member (Scourse, 1991a). The clear evidence for preservation of moraine ridges, and survival of coherent blocks of glacitectonized sediments, favours a recent glaciation. There is certainly no evidence that the glacial sediments and landforms have survived several glacial cycles, with associated high sealevel stands, as would be required if the glaciation had occurred during Stage 16, as proposed by Bowen (1999).

\section{Conclusions}

There is clear evidence that a grounded Irish Sea Glacier reached as far south as the Isles of Scilly. The presence of a distinct limit to the distribution of erratics has long been known, and it has been argued that the exposed granite outcrops of the northern shores have been glacially eroded, or at least scoured clean of loose blocks and debris, whereas to the south of the erratic limit tors, with open joints and balanced blocks, are common. To this evidence we can add the presence of a series of moraine ridges both onshore and extending offshore as boulder ridges, which mark ice marginal positions. The glacier carried marine and lacustrine sediments up and onto the islands, cannibalizing and tectonizing them and also depositing subglacial tills. These were later moved downslope under paraglacial conditions, and in most places have been disaggregated. The original subglacial origin of the tills is clear from their deformation style and micromorphology. There is no possibility that these sediments represent distal glacimarine deposits and they lend no support to the glacimarine model for deglaciation of the Irish Sea basin.

The precise age of the glacial landforms and deposits of Isles of Scilly remains uncertain, but the evidence suggests that an Irish Sea Glacier has only reached so far south on one occasion. The preservation of glacial deposits that have not been completely disaggregated and the existence of clear moraine ridges argue against assigning them to a very distant glaciation, such as Stage 16 as proposed by Bowen (1999). The balance of evidence thus still seems to favour a Late Devensian age (OI Stage 2), as suggested by Scourse (1991a) on the basis of radiocarbon and TL dating. If this is correct, then the most likely explanation for such a large and unprecedented advance is a glacier surge.

\section{Acknowledgements}

The Quaternary Research Association provided a small grant to support the field research. JFH would like to acknowledge the generous support of a Marie Curie Postdoctoral Fellowship, carried out at the University of Glasgow. Aerial photograph extracts are reproduced with kind permission of Global Mapping Limited and XYZ Digital Map Company/English Nature. Thin section preparation was undertaken by Frans Backer (University of Amsterdam), and Peter Chung and John Gilleece (University of Glasgow). Figures and photographs were reproduced by Yvonne Finlayson and Les Hill (University of Glasgow) and Nicola Jones and Anna Ratcliffe (University of Wales Swansea). We wish to thank Jaap van der Meer for permission to use thin sections and microscopic-photographic equipment. Colm Ó Cofaigh, Michelle Clarke and Jim Rose provided constructive reviews and helpful comments.

\section{References}

Ballantyne, C.K., McCarroll, D., Nesje, A., Dahl, S.-O., Stone, J.O., Fifield, L.K., 1998. The last ice sheet in north-west Scotland: reconstruction and implications. Quaternary Science Reviews 17, 1149-1184

Barrow, G., 1906. The Geology of the Isles of Scilly. Memoirs of the Geological Survey of Great Britain. HMSO, London.

Benedict, J.B., 1970. Downslope soil movement in a Colorado alpine region: rates, processes and climatic significance. Arctic and Alpine Research 2, 165-226.

Benn, D.I., 1994. Fabric shape and the interpretation of sedimentary fabric data. Journal of Sedimentary Research A64, 910-915.

Benn, D.I., Evans, D.J.A., 1996. The interpretation and classification of subglacially-deformed materials. Quaternary Science Reviews $15,23-52$.

Boulton, G.S., 1996a. Theory of glacial erosion, transport and deposition as a consequence of subglacial sediment deformation. Journal of Glaciology 42, 43-62.

Boulton, G.S., 1996b. The origin of till sequences by subglacial sediment deformation beneath mid-latitude ice sheets. Annals of Glaciology 22, 75-84.

Boulton, G.S., Peacock, J.D., Sutherland, D.G., 1991. Quaternary. In: Craig, G.Y. (Ed.), Geology of Scotland. The Geological Society, London, pp. 503-543.

Bowen, D.Q., 1984. Introduction. In: Bowen, D.Q., Henry, A. (Eds.), Wales: Gower, Preseli, Fforest Fawr Field Guide. Quaternary Research Association, London, pp. 1-17.

Bowen, D.Q., 1999. Only four major 100-ka glaciations during the Bruhnes Chron? International Journal of Earth Sciences 88, 276-284.

Brewer, R., 1976. Fabric and Mineral Analyses of Soils. Krieger, Huntingdon, NY.

Campbell, S., Hunt, C.O., Scourse, J.D., Keen, D.H., Croot, D.G., 1999. Southwest England. In: Bowen, D.Q. (Ed.), A Revised Correlation of Quaternary Deposits in the British Isles. Geological Society Special Report 23, London, pp. 66-78.

Catt, J.A., 1986. Silt mineralogy of loess and 'till' on the Isles of Scilly. In: Scourse, J.D. (Ed.), The Isles of Scilly Field guide. Quaternary Research Association, Coventry, pp. 134-136. 
Evans, D.J.A., Ó Cofaigh, C., 2003. Depositional evidence for marginal oscillations of the Irish Sea ice stream in southeast Ireland during the last glaciation. Boreas 32, 76-101.

Evans, D.J.A., Rea, B.R., 1999. Geomorphology and sedimentology of surging glaciers: a landsystems approach. Annals of Glaciology 28, 75-82.

Evans, D.J.A., Rea, B.R., 2003. Surging glacier landsystem. In: Evans, D.J.A. (Ed.), Glacial Landsystems. Arnold, London, pp. 259-288.

Eyles, N., McCabe, A.M., 1989. The Late Devensian (22,000 BP) Irish Sea basin: the sedimentary record of a collapsed ice sheet margin. Quaternary Science Reviews 8, 307-351.

French, H.M., 1971. Slope asymmetry of the Beaufort Plain, northwest Banks Island, NWT, Canada. Canadian Journal of Earth Sciences $8,717-731$.

Harris, C., 1981. Periglacial Mass-Wasting: A Review of Research. Geobooks, Norwich 204pp.

Hiemstra, J.F., van der Meer, J.J.M., 1997. Pore-water controlled grain fracturing as an indicator for subglacial shearing in tills. Journal of Glaciology 43, 446-454.

Hiemstra, J.F., Rijsdijk, K.F., 2003. Observing artificially induced strain: implications for subglacial deformation. Journal of Quaternary Science 18, 373-383.

Lambeck, K., 1993. Glacial rebound of the British Isles: 2. A highresolution, high-precision model. Geophysics Journal International 15, 960-990.

McCarroll, D., 2001. Deglaciation of the Irish Sea Basin: a critique of the glaciomarine hypothesis. Journal of Quaternary Science 16, 393-404.

McCarroll, D., Rijsdijk, K., 2003. Deformation styles as a key for unlocking glacial depositional environments. Journal of Quaternary Science 18, 473-489.

van der Meer, J.J.M., 1993. Microscopic evidence of subglacial deformation. Quaternary Science Reviews 12, 553-587.

van der Meer, J.J.M., 1996. Micromorphology. In: Menzies, J. (Ed.), Past Glacial Environments. Butterworth-Heinemann, London, pp. 335-355.

van der Meer, J.J.M., Mücher, H.J., Höfle, H.C., 1992. Micromorphological observations on till samples from the Shackleton Range and North Victoria Land, Antarctica. Polarforschung 62, 57-65.

Menzies, J., 2000. Micromorphological analyses of microfabrics and microstructures indicative of deformation processes in glacial sediments. In: Maltman, A.J., Hubbard, B., Hambrey, M.J. (Eds.), Deformation of Glacial Materials, Special publication 176. Geological Society Publishing House, Bath, pp. 245-258.

Mitchell, G.F., Orme, A.R., 1967. The Pleistocene deposits of the Isles of Scilly. Quarterly Journal of the Geological Society of London $123,59-92$.

Ó Cofaigh, C., Evans, D.J.A., 2001a. Deforming bed conditions associated with a major ice stream of the last British ice sheet. Geology 29, 795-798.

Ó Cofaigh, C., Evans, D.J.A., 2001b. Sedimentary evidence for deforming bed conditions associated with a grounded Irish Sea Glacier, southern Ireland. Journal of Quaternary Science 16, 435-454.

Rijsdijk, K.F., Owen, G., Warren, W.P., McCarroll, D., van der Meer, J.J.M., 1999. Clastic dykes in over consolidated tills: evidence for subglacial hydrofracturing at Killiney Bay, eastern Ireland. Sedimentary Geology 129, 111-126.

Scourse, J.D., 1986. Pleistocene stratigraphy. In: Scourse, J.D. (Ed.), The Isles of Scilly, Field Guide. Quaternary Research Association, Coventry, pp. 12-28.
Scourse, J.D., 1987. Periglacial sediments and landforms in the Isles of Scilly and west Cornwall. In: Boardman, J. (Ed.), Periglacial Processes and Landforms in Britain and Ireland. Cambridge University Press, Cambridge, pp. 225-236.

Scourse, J.D., 1991a. Late Pleistocene stratigraphy and palaeobotany of the Isles of Scilly. Philosophical Transactions of the Royal Society of London B334, 405-448.

Scourse, J.D., 1991b. Glacial deposits of the Isles of Scilly. In: Ehlers, J., Gibbard, P.L., Rose, J. (Eds.), Glacial Deposits in Great Britain and Ireland. Balkema, Rotterdam, pp. 291-300.

Scourse, J.D., Furze, M.F.A., 2001. A critical review of the glaciomarine model for Irish Sea deglaciation: evidence from southern Britain, the Celtic shelf and adjacent continental slope. Journal of Quaternary Science 16, 419-434.

Scourse, J.D., Austin, W.E.N., Bateman, R.M., Catt, J.A., Evans, C.D.R., Robinson, J.E., Young, J.R., 1990. Sedimentology and micropalaeontology of glacimarine sediments from the central and southwestern Celtic Sea. In: Dowdeswell, J.A., Scourse, J.D. (Eds.), Glacimarine Environments: Processes and Sediments. Geological Society Special Publication 53, London, pp. 329-347.

Scourse, J.D., Robinson, E., Evans, C.D.R., 1991. Glaciation of the central and southwestern Celtic Sea. In: Ehlers, J., Gibbard, P.L., Rose, J. (Eds.), Glacial Deposits in Great Britain and Ireland. Balkema, Rotterdam, pp. 301-310.

Scourse, J.D., Hall, I.R., McCave, I.N., Young, J.R., Sugdon, C., 2000. The origin of Heinrich layers: evidence from $\mathrm{H} 2$ for European precursor events. Earth and Planetary Science Letters 182, 187-195.

Scourse, J.D., Evans, D.J.A., Hiemstra, J.F., McCarroll, D., Rhodes, E., 2004. Late Devensian glaciation of the Isles of Scilly: QRA Research Fund Report. Quaternary Newsletter 102, 49-54.

Smith, B.W., Rhodes, E.J., Stokes, S., Spooner, N.A., Aitken, M.J., 1990. Optical dating of sediments: initial quartz results from Oxford. Archaeometry 32, 19-31.

Thomas, G.S.P., Summers, A.J., 1984. Glacio-dynamic structures from the Blackwater Formation, Co. Wexford, Ireland. Boreas 13, $5-12$.

van Vliet-Lanoë, B., 1993. Solifluction activity in the North Atlantic arctic and sub-arctic: the microstratigraphic record of changing climate during the second half of the Holocene. In: Frenzel, B., Matthews, J.A., Glaser, B. (Eds.), Solifluction and Climatic Variation in the Holocene. Palaeoclimate Research 11. Gustav Fischer Verlag, Stuttgart, pp. 279-294.

van der Wateren, F.M., 1999. Structural geology and sedimentology of the Heiligenhafen till section, northern Germany. Quaternary Science Reviews 18, 1625-1639.

Wills, L.J., 1924. The development of the Severn Valley in the neighbourhood of Ironbridge and Bridgnorth. Quarterly Journal of the Geological Society of London 80, 271-314.

Wills, L.J., 1938. The Pleistocene development of the Severn from Bridgnorth to the sea. Quarterly Journal of the Geological Society of London 94, 161-242.

Wingfield, R.T.R., 1994. Pleistocene and Holocene. In: Tappin, D.R., Chadwick, R.A., Jackson, A.A., Wingfield, R.T.R., Smith, N.J.P. (Eds.), United Kingdom Offshore Regional Report: The Geology of Cardigan Bay and the Bristol Channel. British Geological Survey, pp. 76-93.

Wintle, A.G., 1981. Thermoluminescence dating of Late Devensian loesses in southern England. Nature 289, 479-480. 